Dossier

\title{
Actualidad de Federico Engels: los orígenes de la familia, la propiedad privada y el Estado
}

Friedrich Engels: origins of the family, the private property and the State, its relevance today

\author{
Gabriel Santos del Prado González | Universidad Nacional Autónoma de México - MÉXICO | \\ Doctor en Pedagogía en la Universidad Nacional Autónoma de México. Profesor Investigador de Tiempo completo en la Universidad Pedagógica Nacional en Cd. \\ Ayala, Morelos. Correo electrónico: gabrieldprado@outlook.com
}

RESUMEN: Este artículo expone la actualidad y validez de los aspectos fundamentales del pensamiento de F. Engels con respecto de las instituciones cuyo origen analiza a partir de las investigaciones antropológicas y de la prehistoria, realizadas por Bachofen y Morgan principalmente. Aunque la ciencia antropológica se encontraba en sus inicios, la información disponible le permitió a nuestro autor elaborar una teoría coherente y que, en sus líneas generales, ha sido confirmada por investigaciones arqueológicas, antropológicas de mitología comparada, e históricas. Por supuesto, que los avances de la antropología social y los estudios prehistóricos desde hace siglo y medio afinan, y en ocasiones corrigen, algunas afirmaciones de Engels; sin embargo, ello no obsta para que se mantenga en pie la tesis principal y más general de nuestro autor: el carácter histórico e interactivo de la propiedad privada de los medios de producción colectiva, el poder social alienado por una minoría bajo la forma del Estado y la familia patriarcal, que determinó la opresión estructural y cultural de los hombres sobre las mujeres.

Palabras clave: antropología, Estado, propiedad privda, poder social alienado

\begin{abstract}
This paper exposes the relevance of the main aspects of these Engels writing in our days, specially with reference to the institutions which origins he analyzes, mainly based in anthropologic and historical Bachofen and Morgan studies. In spite of the early state of anthropological science, Engels could make a coherent theory that has been confirmed in its general lines by later investigations in archaeology, anthropology, compared mythology and History. Of course, we know that the new developments of social anthropology and prehistorical studious have corrected and refined some Engels assertions, but it doesn't denied his main thesis, that is still valid: the historical and interactive character of private property of the collective production media, the social power which is alienated by minorities under the state, and the structural and cultural oppression on women by men in patriarchal family.
\end{abstract}

Keywords: anthropology, state, private property, alienated social power 


\section{INTRODUCCIÓN}

Federico Engels es no sólo el inseparable colega y amigo de Marx, sino también, por propios méritos, un gran y original pensador. Lo es por la profundidad y originalidad con que aborda diversos temas que sería aquí largo de tratar. Una muestra de ello es la actualidad de su libro Orígenes de la familia, la propiedad y el Estado, que se acrecienta con las más recientes investigaciones sobre las sociedades prehistóricas en la llamada Antigua Europa. Nuestro objetivo es doble: mostrar la validez de la tesis de Engels sobre el carácter histórico de la triple opresión e invitar a la profundización de las ideologías que la ocultan: ideologías estatistas, clasistas y patriarcales Ese es nuestro tema.

Tesis central de Engels es que hay una fuerte interrelación entre los tres aspectos que surgieron imbricados y reforzándose recíprocamente, en un sistema de explotación económica y despotismo de clase y de género: la apropiación privada de los medios de producción requirió la fuerza para apropiarse de ella, origen del Estado. Por su parte, la familia patriarcal aseguró la continuidad de la gran propiedad en manos de los herederos del mismo pequeño grupo.

Si bien muchas desgracias como la vejez y la muerte son, inevitables y sólo queda asumirlas con serenidad; sin embargo, muchas son evitables. Entre éstas, las más grandes causas de infelicidad y sufrimiento se originaron de la tríada cuyo origen exploró Engels: las guerras, la esclavitud, la prostitución, la miseria de grandes núcleos humanos junto a la insultante riqueza de unos cuantos, amén de el obscurecimiento de la mente tanto de los oprimidos como de los opresores, por las ideologías al servicio del poder de la minoría propietaria, condición subjetiva del mantenimiento de esta situación.

La obra de Engels contradice la creencia en que la división de la sociedad en clases, el Estado, la guerra y el dominio patriarcal, con todas las consecuencias mencionadas, tienen su origen en una supuesta naturaleza humana; en cambio, propone que el carácter escindido y fundamentalmente violento de la sociedad tuvo un origen histórico y puede tener, por tanto, un fin.

Estamos viviendo una situación de "policrisis global" y "agonía planetaria" (Morin \& Kern, 1993: 71-113) en el que predomina la injusticia de la miserización estructural de la mayoría de la población mundial —que incluye al menos una quinta parte de los habitantes del planeta en situación de hambruna- junto a una exigua minoría de opulencia insultante (Forrester, 1999). En el último siglo se han realizado guerras de exterminio por el control de la economía global (Chossudovsky, 2002), muchos países son gobernados por oligarquías vestidas de democracia (Chomsky, 1975, 1997, 2004; Forrester, 2002) y la humanidad sufre también por la destrucción acelerada de las condiciones naturales de vida de nuestra especie en aras de la acumulación de capital.

Conocer el origen de esta compleja y alarmante situación requiere una postura transdisciplinar, así como una visión histórica de muy largo plazo, que ha de remontarse a los orígenes de la civilización, tal como la hemos conocido. Además requiere traspasar los espesos velos de las ideologías, que han ocultado, deformado y mistificado la realidad social, manipulando su percepción y comprensión durante miles de años, lo que ha producido la normalización de un mundo de creencias. Las creencias, como bien señaló Ortega y Gasset, no son algo que se posee, sino algo dentro de lo que se vive, que nos rodea por todas partes, como el agua a los peces y el aire a las aves, sin ser percibida su existencia.

Así, resulta de urgente y capital importancia profundizar el estudio crítico de los orígenes de las mayores causas de sufrimiento artificial y evitable y de los obstáculos epistemológicos, especialmente las ideologías, que han sustentado, hasta nuestros días, la normalización de relaciones de opresión y explotación literalmente criminales, lo que no es una exageración doctrinal de tipo sectario, sino una caracterización imparcial hecha a partir de una ética humanista, basada en los valores de libertad, igualdad y fraternidad de la consigna de los revolucionarios franceses pero que, con distintos nombres, han enseñado, desde hace milenios, los grandes maestros de la humanidad, valores tomados en serio. Porque las ciencias sociales no pueden ser ajenas al mundo de los valores, como si se tratara de conocer la dinámica de los astros, sino el resultado de un profundo compromiso con la sobrevivencia de nuestra especie en condiciones que permitan el óptimo desenvolvimiento de la satisfacción de sus necesidades, tanto de las básicas, que compartimos con el resto de los mamíferos, como de las específicamente humanas como un derecho de todos y todas, no sólo de una minoría.

Sin este compromiso, las ciencias socio-humanas son, por decir lo menos, inútiles y superfluas, pero que han llegado a ser, en ocasiones, mistificadoras y cómplices de la barbarie. Además, todos los intentos de un conocimiento axiológicamente aséptico y totalmente objetivo de las realidades humanas han desembocado en ideologías al servicio del establishment. Así, las ciencias sociales han de alejarse del dogma positivista de "la inmaculada percepción", como ha sido caracterizado por Teodoro Roszak y, como hizo Marx, asumir la consigna de Terencio: "nada de lo humano me es ajeno". Esto fue justamente lo que realizó Federico Engels en el estudio que nos ocupa, pionero de las investigaciones en el tema. 


\title{
LA REVOLUCIÓN AGRÍCOLA Y EL PARAÍSO PERDIDO
}

Durante mucho tiempo hubo un gran vacío en el conocimiento de la historia posterior a los inicios de la agricultura, como si súbitamente, como los hongos después de las primeras lluvias, hubiesen surgido Sumer y las otras grandes civilizaciones de Mesopotamia. Durante decenios, aun los más connotados investigadores pensaban que el período neolítico había durado, como máximo, unos dos mil años (Gordon Childe, 1986: 92) y en él, los grupos humanos estaban dispersos y con muy distintos niveles de desarrollo técnico y no constituyeron propiamente una civilización (Ibid: 108-109).

Sin embargo, hoy sabemos que entre ambos períodos hubo un gran lapso de miles de años, que hace poco comenzamos a conocer. Esto es debido a que la arqueología es una ciencia relativamente nueva, que comenzó en el siglo XIX, pero que durante mucho tiempo no se distinguió gran cosa de la actividad de los saqueadores de tumbas y buscadores de tesoros. El estatus y la metodología científica de la disciplina se desarrollaron seriamente a lo más en el periodo de entreguerras y especialmente desde 1945.

No es de extrañar que por ello, hubiera pasado desapercibida la existencia de una gran civilización, que ocupó una enorme extensión de Europa oriental y Cercano Oriente, y que fue una mezcla de pueblos del Mediterráneo con otros del sureste de Europa (Gimbutas, 2014: 29): la llamada Antigua Europa, cuyas culturas se empezaron a conocer a partir de las primeras excavaciones de James Mellaart en Katal Huyuk y Hacilar entre 1961 y 1963, y que constituyen ese eslabón perdido entre el paleolítico y las técnicamente más avanzadas sociedades del calcolítico, del cobre y el bronce. Señala Mellaart que: "Catal Huyuk y Hacilar han establecido un vínculo entre estas dos grandes escuelas de arte. Se puede demostrar una continuidad religiosa desde Catal Huyuk y Hacilar, y así hasta las grandes 'Diosas-Madre' de los tiempos arcaicos y clásicos" (Mellaart, 1967:23-24 en Eisler, 1995:9). Estos fueron los primeros asentamientos urbanos de aquel período que se descubrieron, y que tuvieron vida entre 6,250 y 5,400 a.C., pero sólo fue el inicio de una serie de descubrimientos. Desde 1974 Marija Gimbutas (1995: 27) hizo el recuento de más de tres mil sitios arqueológicos de esta corriente civilizatoria de asentamientos del neolítico y el calcolítico.

Pero vayamos desde el principio: las sociedades de cazadores y recolectoras ajustaban su crecimiento al equilibrio ecosistémico y no podían ir más allá, so pena de exterminar las especies animales y vegetales de las que se alimentaban. La revolución agrícola permitió romper esta barrera ecológica: tanto la agricultura como la ganadería permitían que los niños realizaran labores útiles, entonces más niños no eran sólo más bocas que alimentar, sino también más fuerza de trabajo, lo que mantenía el equilibrio entre las necesidades y su satisfacción; esto permitió un fuerte aumento poblacional en relativamente poco tiempo (Gordon Childe, 1986: 89).

No hay acuerdo entre los investigadores sobre si apareció primero la agricultura o la ganadería. Lo más probable es que en algunos sitios aparecieran simultáneamente y en otros —dependiendo de las diversas condiciones ambientales - surgiera primero un u otra (Gordon Childe, 1986: 86). En todo caso, los estudios más recientes muestran que la agricultura, como principal medio de sustento es muy anterior a lo que se pensaba:

\begin{abstract}
Ahora sabemos que la agricultura —el cultivo de plantas silvestres y la domesticación de animales- se remonta a épocas mucho más antiguas de lo que se creía. De hecho, las primeras señales de lo que los arqueólogos llaman la revolución neolítica o agraria, empiezan a aparecer entre el 9000 y el 8000 A.C., es decir, hace más de diez mil años. (Eisler, 1995: 11)
\end{abstract}

Estos cambios, casi inmediatos al retroceso de la última glaciación, originaron posteriormente la revolución urbana, pero mucho antes de lo que se pensaba, desarrollándose poblaciones de cientos e incluso miles de habitantes y una división del trabajo de notable especialización. Estos cambios se manifestaron en la civilización de la Antigua Europa, entre el 7,000 y el 3,500 a.C., en una amplia zona que abarca, aproximadamente, más de la mitad sur de la actual Italia, toda la península griega y los Balcanes, Europa central y oriental, continuando hacia el norte hasta el Dniéper, así como la costa occidental de la actual Turquía y toda la costa occidental del mar negro. Asimismo, se estableció en las islas del Mediterráneo, especialmente en Chipre y Creta, donde la brillante civilización minoica, fue su último bastión.

Así, encontramos en Jericó, alrededor del 7,000 a.C., casas de ladrillo estucadas, equipadas con hornos de greda con chimeneas y marcos para puertas. (Eisler, 1995:9) y ya para el 6,000 a.C., estaba bien establecida en una amplia región, la revolución urbana, con una notable división técnica del trabajo, que incluía oficios como la alfarería, la cestería, talabartería; practicaban la crianza de todos los animales domésticos que hay actualmente en los Balcanes, menos el caballo. Se fabricaban embarcaciones de vela desde el sexto milenio a. C., y ya se trabajaban el cobre y el oro en el 5,500 a.C. 
casas tienen dos o tres habitaciones y se distribuyen en calles. Los yacimientos de Vinča, tales como Pločnik, Potporanj, Crnokalačka Bara, Medvednjak, Selevak, Drenovac, Grivac y Valač, debieron haber sido ciudades, más que simples aldeas. (Gimbutas, 1995:40).

Aunque encontramos paleoescrituras desde el paleolítico superior, como en Kamyana Mohyla en Ucrania, se han descubierto muestras de escritura de signos ideográficos y mnemónicos usados durante el neolítico, en el VII milenio a.C., como en las cuevas de La Pileta y Nerja en Málaga. Asimismo, durante el VI milenio en Jiahu, provincia de Henan, al norte de China. Todo esto mucho antes de las civilizaciones mesopotámicas, que se creía eran las más antiguas. Esta gran corriente civilizatoria pre-patriarcal tuvo asimismo ramificaciones posteriores, en regiones tan remotas como Mohenjo Daro en el Valle del Indo (2,500 a.C.), que presenta grandes similitudes culturales, especialmente en el simbolismo de su arte.

Hoy, gracias a las investigaciones arqueológicas en distintas regiones de la Antigua Europa, sabemos algo sobre su vida y cosmovisión. Los edificios, los objetos de uso cotidiano y ritual, así como sus manifestaciones artísticas, que en cualquier cultura muestran el carácter de los pueblos que las crean. Del análisis de estos elementos se desprende que:

- Había equidad de género: eran sociedades matrilineales, matrilocales y ginecocéntricas; (Eisler, 1995:12, 28), características de las sociedades que describe Morgan y cuyo análisis recupera, acertadamente, Engels; sin embargo, tampoco hay opresión matriarcal de género, sino armonía entre mujeres y hombres; cierta división técnica del trabajo, pero sin que ello implique superioridad ni dominio de ninguna de las partes. Aunque en las representaciones de la familia divina de Kayal Huyuk hay un orden de importancia: madre, hija, hijo y padre, y la cama de la mujer era más grande que la del hombre:

\begin{abstract}
... a pesar de tal evidencia en la preeminencia de las mujeres tanto en la religión como en la vida, no hay mujeres de una gran desigualdad entre mujeres y hombres. Tampoco hay huellas de mujeres subyugadas u hombres oprimidos (Eisler, 1995:28-29)
\end{abstract}

- La misma autora afirma que la idea del "matriarcado" surge de la conciencia patriarcal, que sólo puede concebir una relación humana en términos de dominio, por lo que si no es patriarcado, entonces debe ser, necesariamente matriarcado. No se les ocurre pensar una sociedad basada en el cuidado de los seres queridos y la procuración de su bienestar. Otro elemento a considerar es que, a diferencia de las religiones en las sociedades patriarcales, donde sólo los hombres pueden ejercer el sacerdocio, en esas sociedades se aprecian sacerdotisas y sacerdotes.

- Eran sociedades esencialmente pacíficas, lo que se desprende desde los criterios para elegir sus asentamientos: no eran lugares militarmente estratégicos, de difícil acceso o con protección natural, sino lugares hermosos, con agua, buena tierra de cultivo y pastoreo, como en Vinca, Butmir, Petresti y Cucuteni (Ibíd. 15, 19-20). Además, no encontramos murallas defensivas ni fortificaciones militares; pese a que muchos pueblos de estas culturas ya usaban los metales, tampoco se han encontrado armas ni instalaciones para fabricarlas en gran escala; solo instrumentos de trabajo, de adorno personal y de los santuarios. Tampoco encontramos en su arte pictórico ni escultórico escenas de batallas, ni prisioneros encadenados, ni grandes tumbas de jefes militares; sólo símbolos geométricos abstractos, representaciones de animales, dioses y diosas y, sobre todo, de la Gran Diosa.

- No eran sociedades escindidas en clases, ni había, por tanto, un Estado que oprimiera a las mayorías, sino líderes que organizaban la vida social en beneficio colectivo, conservando la vida comunitaria:

En el arte neolítico, ni la Diosa, ni su hijo-consorte portan los emblemas que hemos aprendido a asociar con el poder -lanzas, espadas o relámpagos, los símbolos de un soberano y/o deidad terrenal que se hace obedecer a través de la muerte y la mutilación. Aún más, es importante en el arte de este período la carencia de la imaginería gobernante/gobernado, amo/súbdito, tan característica de las sociedades dominadoras (lbíd. 20).

Tampoco había grandes diferencias de fortuna. Eso se nota en las construcciones de Katal Huyuk: las habitaciones eran de un modelo y dimensiones similares (alrededor de $25 \mathrm{~m}^{2}$ o poco más). No había grandes palacios para los poderosos, ni habitáculos miserables para los pobres. Tampoco había monumentos funerarios enormes y fastuosos para los líderes: Todos los entierros eran similares: en la misma habitación familiar. 
La última sociedad de la Antigua Europa se ubicó en Creta, que fue fundada alrededor del 6,000 a.C. quizá por colonos provenientes de Anatolia. La primera actividad económica fue la agricultura, que nunca abandonaron. Paulatinamente desarrollaron otras actividades como la alfarería, los textiles, la metalurgia, la arquitectura y el comercio, que llegó a ser dominante en el Mediterráneo. Llegaron a desarrollar la más notable civilización y el más delicado arte de su época. Inventaron cuatro formas de escritura sucesivamente: jeroglífica, Proto-Lineal, Lineal A y Lineal B. El valor dominantes era el amor a la vida de la Naturaleza toda, expresada en la religión de la Gran Diosa, su personificación, y todo un sistema simbólico heredado de sus antepasados de divinidades tanto femeninas como masculinas: el toro, símbolo de la fuerza viril procreativa, el hacha doble —instrumento de labranza y representación de la mariposa-_; la mariposa y la serpiente, símbolos de la metamorfosis y el renacimiento, todos estos, parte de un universo mítico-simbólico complejo, que sólo ha sido estudiado parcialmente.

Pese a ser una sociedad de gran abundancia, las diferencias de fortuna no habían producido grandes inequidades. Nicolas Platon, superintendente de antigüedades de Creta, que ha realizado investigación arqueológica en la isla durante más de 50 años señala que: "El estándar de vida —aun de los campesinos— al parecer era alto [...] Ninguno de los hogares encontrados hasta ahora, sugiere la existencia de condiciones muy pobres de vida" (En Eisler, 1995:37). Pese a que Creta no fue la sociedad más opulenta de su tiempo, la distribución de la riqueza fue mucho más equitativa que en los imperios patriarcales de entones. Las ganancias de su rico comercio produjeron un grupo social más favorecido; sin embargo, su fuerte tradición cultural solidaria y "maternal" sirvió para que esa riqueza se empleara, en buena proporción, en mejorar las condiciones de vida de toda la población.

A partir del 2,000 a. C., durante el período minoico medio y tardío:

\begin{abstract}
...la centralización no acarreó consigo un gobierno autocrático. Ni impuso la utilización de avanzadas tecnologías sólo para el beneficio de una minoría poderosa, o ese tipo de explotación y brutalización de las masas tan llamativa en otras civilizaciones de la época. Pues aunque en Creta haya existido una clase gobernante opulenta, no hay indicios (más que en posteriores mitos griegos tales como los de Teseo, el rey Minos y el Minotauro) que ésta estuviera respaldada por un poderío armado masivo. (Ibíd. 37-38).
\end{abstract}

Aunque por la mayor riqueza y complejidad social se hizo necesaria una burocracia administrativa más centralizada, esta situación nunca derivó hacia un régimen patriarcal, ni disminuyó el estatus de las mujeres. Además, los dineros siempre se usaron para mejorar las condiciones colectivas de vida: sistemas eficientes de desagüe, cañerías de agua, instalaciones sanitarias y comodidades domésticas en todas las ciudades, calles pavimentadas, fuentes, estanques, obras de irrigación en gran escala. No se dedicaba a la tecnología militar la gran proporción de recursos que los imperios, hasta hoy, le han destinado. Sin duda había una administración de las cosas, paro no se puede hablar de un domino sobre las personas. Hasta la fecha, no se ha encontrado ninguna representación de un rey o jefe dominador, ni indicios de que hubiera esclavitud, al estilo de las demás sociedades que existían en el 2,000 a.C.

Las ciudades no estaban fortificadas ni amuralladas, ni siquiera en la costa y, aunque tuvieron una flota poderosa, que al menos durante 1,500 años les defendió de los "pueblos del mar" y otros piratas y demás potenciales invasores, nunca emprendieron guerras de conquista contra otros pueblos, ni lucharon entre sí sus ciudades, como sucedió frecuentemente entre las ciudades-Estado griegas. La población estaba bien vestida y alimentada — estándares mínimos que las más opulentas sociedades modernas y con tecnología muy superior no cubren- y había tiempo destinado para la fiesta y el culto religioso, donde se integraban la música, el baile, el canto y la acrobacia.

La religión no era de tipo penitencial ni estimulaba el sufrimiento como vía de salvación: era una celebración de la vida. Su rito más famoso, la taurokatharpsia, o juego taurino, era un deporte sagrado en el que, contrariamente a la "fiesta brava" ibérica muy posterior, no se martirizaba ni mataba al noble animal: sólo se jugaba con él y el único muerto podía ser el o la joven que realizaba el ritual de esperar la embestida "tomar al toro por los cuernos" para dar una voltereta sobre su lomo y, quizá, realizar alguna otra acrobacia. Además, la investigación arqueológica ha realizado otros descubrimientos notables: un sistema de caminos pavimentados que comunicaban toda la isla, instalaciones portuarias, ciudades populosas y palacios de varios niveles.

En suma: en la Creta minoica pre-patriarcal, el poder no se entendía como dominio, sino como cuidado, lo que tuvo mucho de actitud maternal. Eisler piensa que la idea de la democracia en la Grecia clásica pudo tener su origen en la Creta minoica y que el pensamiento moderno del poder como responsabilidad, no como dominación, tuvo en ella su remoto antecedente. Esta sociedad, de artística devoción por la vida, tuvo su primer estremecimiento con una invasión de los aqueos alrededor del 1,500 a.C. Pero, al parecer, sucedió un fenómeno que a veces pasa cuando un pueblo de cultura superior es conquistado militarmente: la cultura minoica conquistó pacíficamente a los aqueos, lo que dio lugar a que surgiera lo que han llamado la cultura minoico-micénica. Es difícil encontrar otra explicación, cuando se aprecia que tras la conquista: "...la Diosa y el modo de pensar y vivir que ella simbolizaba, parecen haberse mantenido" (Eisler, 1995:35). 
Creta fue el último enclave de las civilizaciones de la Gran Diosa: todas las demás ya habían sucumbido a las oleadas de invasores que sucesivamente acabaron con ellas, entre el 4,200 y el 2,800 a.C. Eran los pueblos indoeuropeos, que en realidad ni eran indios, ni la mayoría totalmente europeos, ya que llegaron de las estepas del nordeste asiático y europeo:

\begin{abstract}
Y como los arios en India, los hititas y mitanios en la fértil medialuna, los luvianos en Anatolia, los kurgos en Europa Oriental, los aqueos y después los dorios en Grecia, ellos impusieron gradualmente sus ideologías y modos de vida en las tierras y pueblos que conquistaron [también otros, como los] que denominamos hebreos, quienes llegaron desde los desiertos del sur e invadieron Canaán... (Eisler, 1995:50-51).
\end{abstract}

Todos ellos eran pueblos de pastores patriarcales, guerreros, con sociedades fuertemente jerarquizadas dirigidas por una casta guerrero-sacerdotal y dioses celestes masculinos iracundos, celosos y señores de los ejércitos.

El gran aporte de Engels fue señalar la interacción entre la gran propiedad privada de la tierra, la centralización del poder social por una casta guerrera y autoritaria y el patriarcado; sin embargo su hipótesis, muy plausible con la información disponible en su época, de que la causa de la mutación entre el "comunismo primitivo" y la aparición de las mencionadas plagas fue de tipo endógeno, causada por el mero desarrollo de las fuerzas productivas, especialmente las revoluciones agraria, y urbana y el desarrollo de la metalurgia no se sostiene a la luz de las investigaciones más recientes ya que como se ha mostrado, las sociedades agrarias y urbanas vivieron miles de años organizadas en sociedades matrilineales y matrilocales, sin una centralización autoritaria del poder económico y político en manos de una élite explotadora. Además, ya conocían el uso de los metales.

Gimbutas, que siguió cuidadosamente el desarrollo de la tecnología de los metales con excavaciones masivas después de 1945 ha reconstruido su itinerario: en las estepas al norte del mar negro, de donde provenían los pastores no había cobre, sino que aprendieron la metalurgia de los pueblos de la Antigua Europa al sur de las montañas del Caucaso, quienes desarrollaron las primeras aleaciones de cobre-arsénico o cobre-estaño entre el 3,500 y el 2,500 a.C. Estos pueblos pacíficos usaron los metales para fabricar herramientas, adornos y objetos rituales; en cambio: "La aparición de las armas de bronce-dagas y alabardas-, junto con las filosas hachas de bronce, cabezas de mazos, hachas de combate de piedras semipreciosas [...] coincide con las rutas de dispersión del pueblo kurgo." Como señala Gimbutas ( Eisler, 1995: 53).

Lo importante no es que Engels haya errado en su hipótesis sobre las causas de la aparición de la familia patriarcal, la propiedad privada y el Estado en la Antigua Europa. Su gran aporte fue señalar estos hechos como una desgracia enorme para la humanidad, que padecemos hasta la fecha y estudiar su carácter interactivo: la concentración avariciosa de la propiedad de los medios de producción a costa de la mayoría requiere de un aparato que ejerza la violencia sobre los expoliados para controlar su rebeldía y de una estructura patriarcal de la familia que garantice la herencia de dichos medios a la descendencia de la élite propietaria, lo que no sucede con las organizaciones familiares matrilineales que describe Morgan y retoma acertadamente Engels.

Lo relevante en los tiempos que corren, para el éxito de la lucha por transformar la sociedad hacia una más justa, pacífica y libre es reconocer que ésta se tiene que dar, simultáneamente o como la coyuntura lo permita, en los tres frentes: contra el Estado, el capital y la sociedad patriarcal. Si nos ocupamos de un solo factor, los otros dos lo reforzarán, por lo que la lucha se ha de dar, tanto en el cambio de las estructuras económicas, políticas y legales, como en las del pensamiento y la cultura; es decir, la crítica de las ideologías que mantienen las condiciones subjetivas favorables al statu quo, cambio necesario e interactivo con las condiciones objetivas, como se señala en la tercera tesis sobre Feuerbach.

Por lo anterior, en los siguientes apartados me ocuparé de señalar algunas críticas a las ideologías que han sostenido y sostienen el poder de esa trilogía de la desgracia humana. Una de ellas es una concepción profundamente pesimista sobre la naturaleza de nuestra especie, en el supuesto de que sapiens es una mala bestia que requiere un poder autoritario que lo mantenga a raya mediante el terror. Pero que la mujer es peor...

\title{
VISIONES PESIMISTAS SOBRE UNA SUPUESTA NATURALEZA HUMANA
}

Desde la aparición de la propiedad privada de los medios de producción, la concentración del poder social en una casta privilegiada y de la familia patriarcal, se han inventado todo tipo de sofismas ideológicos para legitimar la opresión política y la explotación económica de clase y de género o, al menos, de argumentar el supuesto carácter inevitable de dicha condición, primero con fundamentos míticos, después con afirmaciones naturalistas, que en el siglo XIX asumieron una base pretendidamente científica. 
La Teogonía de Hesíodo (1978: 130-134) nos presenta una visión pesimista de la humanidad actual, una visión de su decadencia desde los hombres de la edad de oro, convertidos en dioses, pasando por estirpe de la edad de plata, que nunca rindieron los debidos honores a los dioses; la de bronce, de hombres fuertes y aguerridos; la cuarta raza, de los héroes o semidioses, más justa y virtuosa, y a quienes concedió Zeus vida eterna y dichosa en la isla de los afortunados. Así llegamos a la humanidad actual de edad del hierro, condenada al fatigoso trabajo, a la guerra y el sufrimiento, constituida por hombres malvados que no respetan al huésped ni al amigo, ni a la palabra empeñada, que desprecian, insultan y maltratan a sus padres en cuanto éstos envejecen. Para Hesíodo, esta quinta humanidad, la nuestra, está condenada: en un futuro los hombres nacerán viejos y serán destruidos por Zeus.

Asimismo, la interpretación corriente del Génesis, presente en todos los pueblos del Libro, muestra al humano como un ser caído, condenado a la fatiga y el dolor, inclinado al mal por nacimiento, debido la desobediencia de nuestros míticos primeros padres. El pesimismo hebreo y griego sobre la humana naturaleza, es también común entre los antiguos romanos, como lo expresa Plauto en su comedia Asinaria (1978, T.1: 93) donde afirma que "lupus est homo homini" (el hombre es el lobo para el hombre), lo que es fácil de pensar para los miembros de una sociedad basada en la guerra y la esclavitud, en la que el espectáculo preferido de todas los estamentos era el sangriento Circo. ${ }^{1}$ Esta concepción pesimista prevaleció durante toda la Edad Media y está presente — de manera aún más acentuada que en Plauto- en pensadores modernos tan influyentes como Thomas Hobbes, quien asume que "La condición del hombre [...] es una condición de guerra de todos contra todos..." (1651/1984: 106) de lo que deduce la necesidad de un Estado que meta orden mediante la violencia y el terror.

En las sociedades esclavistas y en la sociedad feudal las religiones — que originalmente, es decir en el paleolítico y el neolítico eran estrategias didácticas para la realización espiritual- fueros usadas como coartada ideológica para sostener la hegemonía de las castas y estamentos dominantes, así como su opresivo dominio estatal sobre los descendientes de los pueblos conquistados y la explotación de su trabajo, amén de la posición subordinada de las mujeres bajo el patriarcado, añadida a su situación de clase.

Hasta nuestros días, el modelo ideal del Estado ha sido el Imperio Romano, cuyo modelo fue el de Alejandro de Macedonia, cuyo modelo fue el Imperio Persa por él conquistado y así nos podemos retroceder hasta Sumer, el primer Estado con pretensiones imperiales, donde los invasores Kurgos organizaron su poder por primera vez en las tierras conquistadas de la Antigua Europa.

Cabe aclarar que no sólo en los remotos tiempos de las sociedades pre-patriarcales las religiones fueron medio de realización colectiva y solidaria: aún bajo las sociedades estatal-patriarcales suelen ser, de vez en vez, fermento de crítica a la opresión e inspiración para las luchas por la libertad y la justicia, así sea de manera parcial y deformada, lo que se puede apreciar en la dura represión en contra de los movimientos "heréticos" de las religiones en los más diversos contextos. Así sucedió, por ejemplo, con el cristianismo, que en sus primeros tiempos fue duramente reprimido y castigado por el Imperio, que veía en este nuevo culto -mezcla de religión judía, filosofía neoplatónica, mitraísmo y otros elementos- un enorme potencial subversivo y revolucionario.

En una época de grandes crisis, incluida una crisis sin precedente de carácter espiritual y moral, el cristianismo, surgido en uno de los remotos rincones del Imperio y extendido originalmente en mayor medida entre los esclavos, proliferó por todos los dominios imperiales, incluida su capital, y en todos los estamentos, incluida la aristocracia.

Entonces el poder imperial aplicó un cambio de estrategia: ante la imposibilidad de vencer al enemigo, optó por la alianza: Constantino, como se sabe, estableció la tolerancia religiosa y se bautizó -así haya sido en su lecho de muerte- y otros emperadores, como Justiniano, la convirtieron en religión oficial. No es este el espacio para narrar la accidentada conversión del Imperio. Baste decir que, como se ha señalado, si bien Roma se cristianizó, el cristianismo se romanizó; es decir, se convirtió en ideología al servicio del Imperio (Kee:1990): su estructura, originalmente democrática, se jerarquizó, la conducta de sus miembros se normó mediante el derecho canónico, calcado del derecho estatal romano, se estableció la doctrina oficial, se reprimieron las expresiones del cristianismo contrarias a los intereses de Roma, se depuraron los libros sagrados, seleccionando, para ser incluidos en el canon, sólo aquellos aceptables de acuerdo al criterio de los agentes de la policía política del Emperador, destruyendo los considerados heréticos. Algunos se salvaron de la destrucción, gracias a que fueron escondidos y sobrevivieron hasta hoy: los apócrifos, lo que etimológicamente no significa falsos, sino, justamente "escondidos". En fin, que el Imperio limó garras y colmillos al potencial revolucionario del cristianismo ${ }^{2}$ para ponerlo a su servicio, proceso que inició Constantino.

El Imperio de Occidente se derrumbó, pero se formó una nueva clase dominante, integrada por los señores feudales, que eran jefes de bandas armadas que luchaban entre sí por el control del territorio y la población, verdaderos capos del crimen organizado, que asolaban las poblaciones, llevando muerte y destrucción por donde pasaban, robando, violando a las mujeres y aterrorizando a toda la población. Además vendían protección a los

1 Quizá algo parecido suceda en nuestra sociedad moderna, en la que el género periodístico más leído es la nota roja, especialmente en la prensa amarillista, y las películas de Hollywood más taquilleras son las de "acción", que suelen ser tan o más sangrientas que el circo romano, pero que se miran con la buena conciencia del fariseísmo de saber que las escenas de crueldad, violencia y muerte son simuladas. Mas la fascinación es la misma.

2 Potencial revolucionario que ha sido defendido por autores tan notables como Lev Tolstoi (2011), cuya fama de excelente narrativa es indiscutible, pero que se ha propiciado una especie de conspiración de silencio en torno a su pensamiento político y religioso, y Jacques Ellul (2005). 
campesinos, relación que fue la base del feudalismo. Los "jefes de jefes" recibieron el título de reyes, y los reyes más poderosos aspiraban al título de emperador. Algunos lo lograron, como el rey de los francos, Carlomagno, emperador del Sacro Imperio Romano-Germánico. En fin, que todos los imperios europeos tienen en Roma su referente mítico. Bisancio, continuación de Roma en Oriente fue el modelo legal, político y administrativo para la Rusia de los zares y su organización burocrática poco se modificó en la Unión Soviética.

No es casual que en todas las escuelas y facultades de Derecho de Occidente se estudie el derecho romano y el latín, la lengua de los términos legales. Tampoco lo es, que el tercer Reich tomara como modelo al primer Reich: Roma; ni que el fascismo haya tomado su nombre de las fascis, haces de varas, que fueron un símbolo importante, que representaba la unidad del Imperio. Por su parte, el mayor poder estatal del siglo XX, los Estados Unidos de América, muestra a las claras su vocación imperial al llamar "Capitolio" al edificio que alberga las dos cámaras del Congreso y que al se llamara Empire State, al que fue durante varios decenios el edificio más alto del mundo en Nueva York.

Pero regresemos al medioevo: los autodenominados "nobles" basaron su hegemonía en la asociación con la jerarquía eclesiástica. Los obispos y cardenales eran los hijos segundos o terceros de los señores feudales y el obispo de Roma logró la supremacía sobre los otros obispos que, tradicionalmente, habían sido sus pares y así surgió el título de Papa, que era también un muy poderoso señor feudal, con ejército propio y una extensa red de apoyo político y financiero diseminada por toda Europa. Monarca absoluto de los Estados Pontificios, que llegaron a ocupar la mitad de la actual Italia, en sus dominios, era dueño y señor de vidas y haciendas. Durante todo el medioevo, los reyes, en alianza estrecha con la Iglesia, reprimió duramente los movimientos — generalmente campesinos y que conservaban costumbres de solidaridad comunitaria- que cuestionaban, desde el cristianismo, la legitimidad del Rey y el Papa (Le Goff, 1987).

El Papa era además supremo censor del pensamiento, líder absoluto —en términos gramscianos- de la hegemonía que legitimaba el poder de la clase dominante en toda Europa, Los otros señores feudales le temían y buscaban su alianza, que era de suma importancia para la legitimación de su gobierno, pues requerían de su bendición, con la que podían presumir de que eran reyes "por la gracia de Dios". Todavía en el siglo XX, las monedas españolas tienen grabada esta leyenda junto al rostro del rey en funciones al momento de ser impresas.

Al fin del feudalismo, la nueva clase dominante, que surgió de entre algunos habitantes enriquecidos de los burgos, sin títulos nobiliarios ni feudos, pero con el poder del dinero, disputó duramente el poder a la vieja clase feudal, pero no podía legitimarse por medio de la institución religiosa tal como existía debido a su centenaria simbiosis. Por ello, en los países del norte de Europa se dieron cismas religiosos — la Reforma protestante- que se adaptó con rapidez a las nuevas condiciones, modificando su doctrina y su moral, como mostró Max Weber (2001), aunque para él, primero se dio la Reforma y luego se desarrolló el capitalismo. No entraremos en esa discusión. Pero hubo algo que no se modificó: el pesimismo veterotestamentario sobre la naturaleza malvada y pecadora del caído ser humano, que sólo puede ser redimido por la gracia, don divino que es otorgado de manera selectiva a los elegidos, de acuerdo a criterios inescrutables para la limitada inteligencia del ser humano. Lo cierto es que ambas, la ideología de las iglesias reformadas y el dominio burgués han sido de lo más compatibles.

Pero allí donde la nueva clase dominante se sintió más segura incluso intentó, sin éxito, derrocar al poder eclesiástico en sí, como en la Revolución Francesa. De todas formas, a la burguesía no le bastó una legitimación religiosa, mal parada desde las duras críticas de los filósofos de la llustración y el triunfo de La Gran Revolución; entonces esta nueva oligarquía inventó dos religiones laicas: el nacionalismo y el cientificismo. Bajo estas nuevas fuentes de legitimación, han seguido medrando en la modernidad —y en la posmodernidad— la propiedad privada de los medios de producción, el dominio masculino sobre las mujeres y el Estado. Pero la argucia de la nueva clase dominante fue involucrar en su lucha a toda la población, apelando a una engañosa igualdad política, irreal sin un control colectivo de los medios de producción. Esa es la principal limitación de la democracia burguesa que es, en realidad, una oligarquía embozada y que se presta, incluso, para ocultar una dictadura unipersonal, como expuso claramente Maurice Joly (1984).

En el nacionalismo como para-religión estatal ha sido estudiado por diversos autores. La vieja Roma tuvo su religión de Estado con el panteón de los dioses que, en su mayoría fueron adoptados del Olimpo griego, pero los estados modernos hicieron del nacionalismo en sí una nueva religión, reciclada de la adoración del antiguo ídolo Moloch. El Estado mismo es venerado, bajo la aparentemente maternal figura de la Patria. El sentimiento, espontáneo y natural de todos los pueblos, de amor a su tierra, su gente, su lengua, y costumbres, ha sido manipulado en beneficio de las oligarquías locales mediante el fomento de un exclusivismo sectario, chauvinista, etnocéntrico, muchas veces impregnado de racismo.

Esta religión estatal copió los recursos que las religiones más tradicionales han usado para influir en los sentimientos y el pensamiento de los feligreses. Así, tiene himnos — género originalmente religioso, pero aplicado a crear una identidad homogénea, en un conglomerado culturalmente diverso. Muchas veces los himnos nacionales recurren a figuras poéticas religiosas, ejemplo de lo cual es el Himno Nacional Mexicano, de una nación constitucionalmente laica, pero en la que figuran el ángel del cielo y el dedo de un dios antropomorfo. Se crearon asimismo, nuevos ritos, para sustituir los de la religión, que marcan los eventos relevantes de la vida: nacimiento, 
iniciación a la vida adulta, matrimonio y muerte. El registro civil sustituye al templo y la Epístola de Melchor Ocampo a la de Pablo a los corintios. En los rituales cívicos se veneran objetos sagrados como una bandera nacional —en México comúnmente llamada Lábaro Patrio, en recuerdo del símbolo cristiano-mitraísta enarbolado por Constantino en la batalla del Puente Milvio_, la campana que tañó el cura Hidalgo para declarar la Independencia, los restos mortuorios de los héroes, culto parecido al de las reliquias óseas de los santos cristianos, o la banda tricolor que luce en el pecho el presidente en las ocasiones solemnes -sospechosamente parecida a la estola de los curas católicoscomo en la noche del 15 de septiembre, en la que lanza vivas a cada uno de los héroes y algunas heroínas, acto que recuerda las rogativas a los santos católicos.

La religión del Estado también copia de las viejas teocracias la construcción de templos y monumentos, especialmente de tipo funerario: "...desde tiempo inmemorial, el poder ha estado vinculado con la posesión de los difuntos, que terminaban por convertirse en la divinidad del hogar. Con la sepultura se materializaba la legitimación del vínculo entre los difuntos y sus sucesores..." ( Sánchez Cordero, J. "Los monumentos del silencio" en revista Proceso. No1862, 08/07/2012)

Hay que reconocer que el nacionalismo es un útil recurso para motivar el ardor en la defensa de la patria amenazada; sin embargo, los invasores también actúan en nombre de su patria.

En cuanto al cientificismo, una de sus manifestaciones es el darwinismo social.

En la modernidad, ha habido una diversidad de posiciones como alternativa con respecto del alienante pesimismo sobre la naturaleza humana: como el optimismo de Rousseau, o la tesis de Locke de la tabula rasa -quien defendía la primacía de las influencias sociales-, así como la visión de Freud, quien propone una interacción entre las pulsiones biológicas del ello, la influencia social del superyó, y la acción del yo, emparedado entre los dos anteriores, pero que tiene la posibilidad de comprender las determinaciones originadas en las otras instancias para manejarlas conscientemente mediante la terapia psicoanalítica.

A pesar de todas estas y otras opciones para una comprensión distinta del ser humano, la vieja concepción pesimista sobre su naturaleza se ha reforzado por el darwinismo social de Herbert Spencer y T.H. Huxley, entre otros, que parte de una lectura parcial y amañada de Darwin, como lo mostró en su tiempo Pedro Kropotkin en su Ayuda mutua... (1989), y más recientemente Ashley Montagú (1990).

Los darwinistas sociales sostienen la tesis del gran maestro de la teoría de la evolución sobre el papel de la competencia y la lucha por la vida en la que los más fuertes y capaces sobreviven y se reproducen. Mecanismo que se manifiesta, por ejemplo, en la selección del macho alfa en muchas especies de mamíferos, incluidos algunos antropoides, nuestros más cercanos parientes; sin embargo, aunque la lucha y la competencia tienen su lugar, estos autores omiten la enorme cantidad de casos observados y descritos por Darwin, en los que la conducta cooperativa, la ayuda mutua, tiene un gran valor adaptativo y de supervivencia, en muchas ocasiones más importante.

De esta manera, si bien la cadena alimenticia requiere que unas especies conservemos nuestra vida a costa de la de los miembros de otras, son sumamente raros los casos en los que se mata a miembros de la misma especie. Así los felinos y los cánidos son depredadores y se alimentan de otros animales, pero lo hacen cooperando en equipo. Además, también sus potenciales víctimas se defienden en equipo, muchas veces con notable éxito, como en el caso de las cebras en el África, que se defienden de los leones, somo los caballos de las llanuras de Eurasia y Norteamérica contra el ataque de las jaurías de lobos. Ambos -cebras y caballos- siguen la misma estrategia: forman un círculo exterior, lo más cerrado posible, viendo hacia el exterior, de modo que los atacantes se enfrentan con una andanada ce coces, potencialmente mortales. Si los atacantes -que también trabajan en equipo- logran penetrar ese círculo, se enfrentan con un segundo círculo defensivo formado por las hembras; en el centro se ubican los potrillos, pero resulta sumamente difícil llegar hasta ellos, a menos que logren desorganizar la defensa; en caso de no lograrlo es frecuente que los asaltantes se retiren, incluso con algunas bajas.

Sería imposible dada la extensión disponible para este trabajo, exponer la gran cantidad de casos que menciona Darwin y recuerda Kropotkin entre miembros de la misma especie y de especies muy distintas, en todos los niveles de la taxonomía biológica y en todos los contextos ecológicos. Baste mencionar que el desarrollo de los seres pluricelulares surgió de la cooperación y progresiva especialización entre los miembros de colonias de vegetales y animales unicelulares originalmente idénticos. Sin embargo, y especialmente éntrelos apologetas del neoliberalismo, se sigue repitiendo hasta la saciedad la necesidad de la competitividad y la lucha por la sobrevivencia de los más aptos como inflexible ley de la naturaleza, que resulta igualmente inflexible en su aplicación a las sociedades humanas.

Lo peor es que la realidad histórica durante miles de años, la historia conocida hasta hace poco, que supuestamente comenzaba en Súmer, parece reforzar esta idea pesimista cuya genealogía hemos repasado someramente, desde Hesíodo, el Génesis y Plauto, pasando por Hobbes y todas las ideologías estatistas hasta el darwinismo social, porque dicha historia es la historia de la opresión y la esclavitud del hombre por el hombre y de la mujer por el hombre, en la que esta ha sido moneda matrimonial de cambio ente los poderosos en el mejor de los casos y botín de guerra en el peor, hasta la fecha. 
Y aunque esto fuera así, el ser humano es una especie que ha proliferado justamente gracias a que ha creado y desarrollado conductas, generalizadas socialmente, que se desvían de los dictados de la naturaleza y que, en conjunto, constituyen la cultura.

\title{
LA FAMILIA PATRIARCAL
}

En cuanto al patriarcado, que como vimos se impuso con las invasiones de los Kurgos, es necesario ir hasta la raíz, para arrancar de la cultura su carácter misógino. Los límites de este trabajo me impiden explicar más detalladamente mi propuesta educativa con enfoque de género, por lo que sólo expondré un asunto importante por su posible impacto. Para un enfoque radical de la educación es necesario ir a la raíz, llegar hasta el núcleo duro de la mentalidad dominante de las mayorías, que está conformado por las creencias religiosas. Pero no es fácil llegar a ellas: es necesario implementar una estrategia de desaprendizaje. En una educación crítica no sólo hay que aprender a aprender; sobre todo, hay que aprender a desaprender. Pero la lucha por la hegemonía que propuso Gramsci, que implica llevar a las masas a un nivel superior de coherencia en su pensamiento, se enfrenta al un grueso muro de prejuicios de la ideología dominante desde hace milenios. Considérese que el máximo Best Seller en Occidente es un conjunto heterogéneo de libros escritos desde el 800 a.C., hasta el siglo II d.C., y que mucha gente lo sigue usando como referencia máxima de su conducta moral.

En esta obra encontramos de todo: desde la indiscutible norma llamada "regla de oro", que invita a tratar a otros como se quiera ser tratado, hasta la justificación de genocidios y otros crímenes horrendos. La Escritura, estudiada de manera acrítica es uno de los mayores obstáculos para formar una mentalidad que nos permita llegar a la equidad de género.

Uno de los factores que más han ayudado a reforzar el dominio patriarcal es el dualismo. De origen persa, la idea de que la realidad está constituida por dos principios radicalmente opuestos -incluso enemigos- llegó a occidente a través de los pitagóricos, Sócrates, Platón el judío helenizado Pablo de Tarso y Plotino, autor preferido de Agustín, Obispo de Hipona. En esta ideología el espíritu, principio divino, debe sojuzgar a la materia, vil y despreciable; dualismo que se manifiesta en la contradicción entre cuerpo y alma. El primero ha de ser dominado y mortificado, incluso torturado porque, como reza el Catecismo del padre Ripalda (1934: 17) -con gran influencia desde la Contrarreforma- los enemigos del alma y la salvación son el demonio, el mundo y la carne.

Detengámonos un momento para un pequeño análisis:

"La carne" se refiere, indudablemente, al cuerpo humano, en especial el de la mujer que, según la Torá, es impuro casi por definición: la mujer será impura durante siete días de su menstruación o más si esta se prolonga y siete días adicionales. También será impura su cama, la silla y cualquier otro objeto en que se siente y quien toque estos objetos también lo será (Lev. 15:19-29). Todo ello implica que la impureza -o inmundicia, como dicen algunas traducciones- dura, al menos, la mitad de cada mes. Además:

\begin{abstract}
...Cuando dé a luz una mujer y tenga un hijo, será impura durante siete días [...] pero ella quedará en casa durante treinta y tres días en la sangre de su purificación; no tocará nada ni irá al santuario hasta que se cumplan los días de su purificación. Si da a luz una hija, será impura durante dos semanas, como al tiempo de su menstruación, y se quedará en casa durante sesenta y seis días en la sangre de su purificación. Cuando se cumplan los días de su purificación, según que haya tenido hijo o hija, presentará ante el sacerdote, a la entrada del tabernáculo de la reunión, un cordero primal en holocausto y un pichón o una tórtola en sacrificio por el pecado (Lev. 12: 2-6)
\end{abstract}

Si consideramos que los embarazos en aquel tiempo eran de lo más frecuente, la mayor parte del tiempo las mujeres eran inmundas..

El mundo, segundo enemigo del alma, se refiere a la materia, la físis de los griegos; es decir, la naturaleza, que de Gran Madre nutricia y origen de gentes y dioses, pasa a ser masa inerte, estúpida, vil y despreciable bajo el dualismo, lista para ser destruida y explotada para obtener un beneficio económico o militar. Ya durante las guerras púnicas grandes extensiones de bosque fueron destruidas para construir las flotas guerreras de Roma y Cartago. Destrucción que se repitió fuertemente incrementada durante los enfrentamientos entre la flota de su Majestad Británica y la Armada Invencible: los bosques de Inglaterra y Castilla acabaron en el fondo del mar.

El ecocidio que se está realizando desde el fin de la Segunda Guerra Mundial hasta el presente amenaza la vida y la salud de nuestra especie en beneficio de las grandes corporaciones es grandemente favorecido por el pensamiento dualista, aún vigente en gran parte de la población de Occidente. 
El demonio judeocristiano, último "enemigo" del alma según el P. Ripalda no es más que la satanización de la sexualidad, bajo la figura de las antiguas divinidades astadas, que representaban el poder generador de lo masculino en la religión de la gran diosa Harris, (2002; Murray, 2012)

Engels, al estudiar de manera interrelacionada la trinidad de la opresión, fue un precursor del pensamiento complejo, que va más allá de una causalidad lineal y mecánica, mostrando la inter-retroacción que existe entre los fenómenos estudiados por distintas ciencias.

Hoy es necesaria una comprensión crítica, que muestre las interrelaciones entre todos los factores que integran el sistema de dominación vigente e integre las luchas sectoriales de manera coherente: anti-capitalistas, demócratas radicales, feministas, ecologistas, luchadores por los derechos humanos, para llegar a la meta, que vio con claridad Federico Engels: trascender la propiedad privada de los medios de producción, del poder centralizado opresor y del patriarcado hacia una sociedad con libertad y equidad en fraternidad. Que así sea.

\section{REFERENCIAS BIBLIOGRÁFICAS}

Carrillo Castro, A. (1996), El dragón y el unicornio. México, Cal y arena,

Clastres, P. (1978), La sociedad contra el Estado. Tr. Por Ana Pizarro. Caracas, Monte Ávila,

Clastres, P. (1981), Investigaciones en Antropología política. Tr. por Estela Ocampo. Barcelona, GEDISA,. (Col. Hombre y sociedad; Serie Mediaciones, 4).

Capra, F. (1992), El Tao de la física. 3a ed. Tr. por Juan J. Alonso Rey. Madrid, Luis Cárcamo.

Chomsky, N. (2004), Piratas y emperadores. Tr. por Jordi Vidal. Barcelona, Ediciones "B".

Chomsky, N. (1975), Por razones de Estado. Tr. por Joaquím Sempere. Barcelona, Ariel, (Demós. Biblioteca de ciencia política.)

Chomsky, N. \& Dieterich, H. (1997), Los vencedores; una ironía de la historia. Tr. por Martxel Mariscal y Anton Haild. México, Joaquín Mortiz.

Chossudovsky, M. (2002), Guerra y globalización antes y después del XI / IX / MMI. Tr. Por Berta Ruiz de la Concha. México, Siglo XXI,

Eisler, R. (1995), .El cáliz y la espada. 5a.ed. Tr. por Renato Valenzuela. Santiago de Chile, Cuatro Vientos Editorial,

Engels, F. (S/F), El origen de la familia, la propiedad privada y el Estado. En Marx, Carlos y F. Engels. Obras escogidas. Moscú, Progreso.

Forrester, V. (2002), Una extraña dictadura. 2ª ed. Tr. Por Daniel Zadunaisky. México, Fondo de Cultura Económica.

Gimbutas, M. (2014), Diosas y dioses de la vieja Europa (7000-3500 a. C.) Tr., por Ana Parrondo. Madrid, Siruela. (Col. El Árbol del Paraíso, 79).

Gordon Childe, V. (1986), Los orígenes de la civilización. Tr. por Elí de Gortari. México, Fondo de Cultura Económica. (Breviarios, 92).

Graves, R. (1983), La diosa blanca 1; Gramática histórica del mito poético. Tr. por Luis Echávarri. Madrid, Alianza Editorial. (El libro de bolsillo, 948).

Graves, R. (1988), Los mitos griegos. Tr. por Luis Echávarri. México, Alianza Editorial,. 2V. (El libro de bolsillo, 1110 y 1111).

Harris, M. (2002), Vacas, cerdos, guerras y brujas; Los enigmas de la cultura. Tr. por Juan Oliver Sánchez Fernández. Madrid, Alianza Editorial.

Hesíodo. (1978), "Trabajos y días" en Obras y fragmentos. Tr. Por Aurelio Pérez Jiménez y Alfonso Martínez Díez. Madrid, Gredos, Hobbes, T. (1984), Leviatán. $2^{a}$ ed. Tr. por Manuel Sánchez Sarto. México, Fondo de Cultura Económica.

Joly, M. (1984), Diálogo en el infierno entre Maquiavelo y Montesquieu. Tr. por Matilde Horne. México, Múchnik Editores.

Kee, A. (1990), Constantino contra Cristo; el triunfo de la ideología. Tr. por Jordi Beltrán Ferrer. Barcelona, Roca.

Kropotkin, P. (1989), El apoyo mutuo, un factor de la evolución. 3a ed. España, Ediciones Madre Tierra.

Lafargue, P. (1970), El mito de Prometeo. En El derecho a la pereza. Tr. por Juan Giner. México, Grijalbo, (Colección 70’, 99).

Lagarde, M., Terrazas, A. \& Vargas L. A. (Coords.) (2017), Parentalidad 2: Antropogénesis. México, Universidad Autónoma de Barcelona/ Ministerio de Economía, Industria y Competitividad/ Libertad bajo palabra Ediciones.

Le Goff, J. et al. (1987), Herejías y sociedades en la Europa preindustrial (Siglos XI- XVIII). Tr. por Flora Guzmán et al. Madrid, Siglo XXI / Ministerio de Educación y ciencia. (Historia de los movimientos sociales).

Mellaart, J. (1967), Catal Huyuk. New York, Mc. Graw- Hill.

Mellaart, J. (1975), The neolithic of the near east. New York, Scribner,

Montagu, A. (1990), La naturaleza de la agresividad humana. Tr. Por Antonio Escohotado. Madrid, Alianza Editorial, (Alianza Universidad, 222).

Murray, M. (2012), El dios de los brujos. Tr. por Juan José Utrilla. México, Fondo de Cultura Económica.

Plauto, T. M. (1978), Comedias. Tr. Por Germán Viveros. México, UNAM, 3V. (Bibliotheca Scriptorvm graecorum et romanorum mexicana).

Ripalda, J. (1934), Catecismo de la doctrina cristiana. México, Murguía.

Tolstoi, L. ( 2011), El reino de Dios está en vosotros. 4ª ed. Barcelona, Kairós.

Sahlins, M. (1972), Stone age economics. Chicago, Aldine- Atherton.

Weber, Max. (2001), La ética protestante y el espíritu del capitalismo. 5a ed. Tr. por Luis Legaz Lacambra. México, Colofón. 
How to cite this article: Santos del Prado González, G. (2020). Actualidad de Federico Engels y los orígenes de la familia, la propiedad privada y el estado. Religación. Revista De Ciencias Sociales Y Humanidades, 5(23), 51-62. Recuperado a partir de http://revista.religacion.com/index.php/religacion/article/view/595

Submitted: 12 January 2020 Accepted: 15 March 2020 Published: 31 March 2020

Religación. Revistais de Ciencias Sociales y Humanidades is a peer-reviewed open access journal published by CICSH-AL Centro de Investigaciones en Ciencias Sociales y Humanidades desde América Latina |Religación|

OPEN ACCESS 